\title{
Age-related Changes in the Number of Osteoclasts and Whole Medullary Cells Recovered in Early Growing Bone of Rats
}

\author{
Hiromasa Inoue, Dar-Zen Ho and Choji Uchiyama \\ Department of Oral Bacteriology (Chief: Prof. Choji Uchiyama) \\ Kyushu Dental College, Kitakyushu, Japan \\ Recieved on 13th August, 1986.
}

Key words : Osteoclast/Bone growth/Bone marrow cell

\section{Introduction}

Progress in the study concerned with osteoclast was accelerated by the use of the isolation method of living cells ${ }^{1-3}$. In recent years, bone resorption in vitro could be carried out by isolated osteoclasts $\left.{ }^{4}, 5\right)$. These reports were restricted in the cell source and their experiments were carried out on a very small scale. It seems to be important that osteoclasts are isolated in large number from rats, which are commonly used animals in the physiological experiments. Although the authors isolated osteoclasts from 20-day-old rats, the enrichment and the number were insufficient ${ }^{6}$. In order to enlarge the number of isolated osteoclasts, the number of recovered osteoclasts was counted in the cell suspension prepared from growing bone of rats.

We reported here that recovered osteoclasts and whole medullary cells changed dramatically in number in a course of days after birth.

\section{Materials and Methods}

\section{a. Animals}

Wistar strain newborn rat sucklings were sacrificed at appropriate days between 1st and 20th day after birth.

b. Preparation of the whole medullary cell suspension

The dishes, the pipettes and the centrifuge tubes used were siliconized beforehand to minimize the adhesion of cells. Two femora were taken, freed from surrounding soft tissues, dissected longitudinally, and the distal epiphysis was cut off to exclude the effect of second ossification. In the first curettage the shafts were dipped in phosphate buffered saline (PBS), pH $7.2(0.5-2.0 \mathrm{ml}$ per bone $1 \mathrm{~g})$. The medullary cells were scraped off with the ends of a pair of tweezers until the reddish medullary cells could be no longer seen in appearance on the endosteal surface. After the first curettage the shafts were dipped again in the same volume as the first curettage, and endosteal surface cells were scraped off for the same period as the first curettage. 
After the second curettage the shafts were then used in the third curettage. In each curettage, cell masses and the scraped bone fragments were pipetted slowly in PBS to release the cells from clumps. Cell suspensions, which were recovered in the first, second and third curettages, respectively, were used as whole medullary cells. The numbers of cells and osteoclasts in these cell suspensions were counted.

c. Bone marrow cells and bone surface cells

The split shafts, cut off at distal epiphysis, were dipped in PBS under the same conditions as the curettage. The cells in bone marrow were flashed out in the stream of PBS. The cells were pipetted slowly to be separated into individual from the mass. Resulting cell suspension was called as bone marrow cells. After the flashing remaining bone was dipped in PBS again, endosteal of the bone was scraped, and the cell suspension was prepared from the scraped bone fragments in the same condition as the curettage. Thus the cell suspension obtained was called as bone surface cells.

d. Percoll gradient centrifugation

The cell suspension to which PBS was added upto $1.5 \mathrm{ml}$, was applied on $8 \mathrm{ml}$ of the linear gradient between $0 \%$ and $50 \%$ Percoll against PBS containing BSA $(1 \mathrm{mg} / \mathrm{ml})$, and centrifuged at $400 \times \mathrm{g}$ for $20 \mathrm{~min}$ at $4{ }^{\circ} \mathrm{C}$. Each one $\mathrm{ml}$ of fraction was collected from top to bottom, and numbered as Fra. 1, Fra. 2 and so on. The cells in each fraction were washed by centrifugation, suspended with $0.2 \mathrm{ml}$ of PBS, counted the number and spreaded on slide glass to count the osteoclast number.

e. Counting of cell number

Ten $\mu 1$ of cell suspension, which was prepared as described above was diluted with $10 \mathrm{ml}$ of Isoton II (Coulter Electronics Inc., Hialeah, Florida), and applied to Coulter Counter (Coulter Electronics Inc.) to count cell number four times.

\section{Results}

Osteoclast and whole medullary cells were obtained by several operations of curettage from femora and their numbers were counted. Table 1 showed an apparent cell recovery which was expressed as the percentage of cell number obtained in each curettage to the sum of cell number in all curettages. In the first curettage the values were rather constant and high throughout postnatal days in both total cells and osteoclasts. This result shows that the first operation of curettage seems enough to obtain most part of osteoclasts and the other cells.

It was shown that osteoclasts increased in the following days (Fig. 1). The osteoclast number began to increase on 7 th day and it reached a maximum on 16th day. The changes in sum of osteoclast nuclei resembled those in osteoclast number (Fig. 2). The average nuclear number of osteoclast changed a little, 4.6-6.0, in early growing bone.

The whole medullary cell number increased day by day. The rate of increase was low from birth to 7 th day. The rate rose suddenly on 9 th day and kept high upto 
Table 1 Propotion of number of whole medullary cells and osteoclast recovered to the sum after a series of curettages of rat femora.

\begin{tabular}{|c|c|c|c|c|c|c|}
\hline \multirow{2}{*}{ Day old } & \multicolumn{3}{|c|}{ Whole medullary cells } & \multicolumn{3}{|c|}{ Osteoclast } \\
\hline & 1st & 2nd & $3 \mathrm{rd}$ & 1st & 2nd & $3 r d$ \\
\hline $3 r d$ & $76.1 \pm 1.5$ & $23.9 \pm 0.9$ & $\mathbf{a}$ & $\begin{array}{l}\text { b } \\
>97.9 \pm 0.5\end{array}$ & $\begin{array}{l}\mathrm{b} \\
\langle 2.1 \pm 0.5\end{array}$ & a \\
\hline 7 th & $67.5 \pm 3.7$ & $32.5 \pm 2.5$ & $\ldots$ & $81.1 \pm 2.3$ & $18.9 \pm 0.6$ & 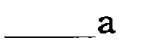 \\
\hline 14th & $79.6 \pm 4.2$ & $12.5 \pm 2.3$ & $7.8 \pm 1.4$ & $93.5 \pm 5.2$ & $5.2 \pm 1.9$ & $1.3 \pm 0.3$ \\
\hline
\end{tabular}

a. Remaining bone shafts destroyed so hard that the curettage could not be carried out any more.

b. Osteoclasts could not be seen in each smear of second curettage. Each number shown in table reveals the average of the proportion of the two separate experiments.

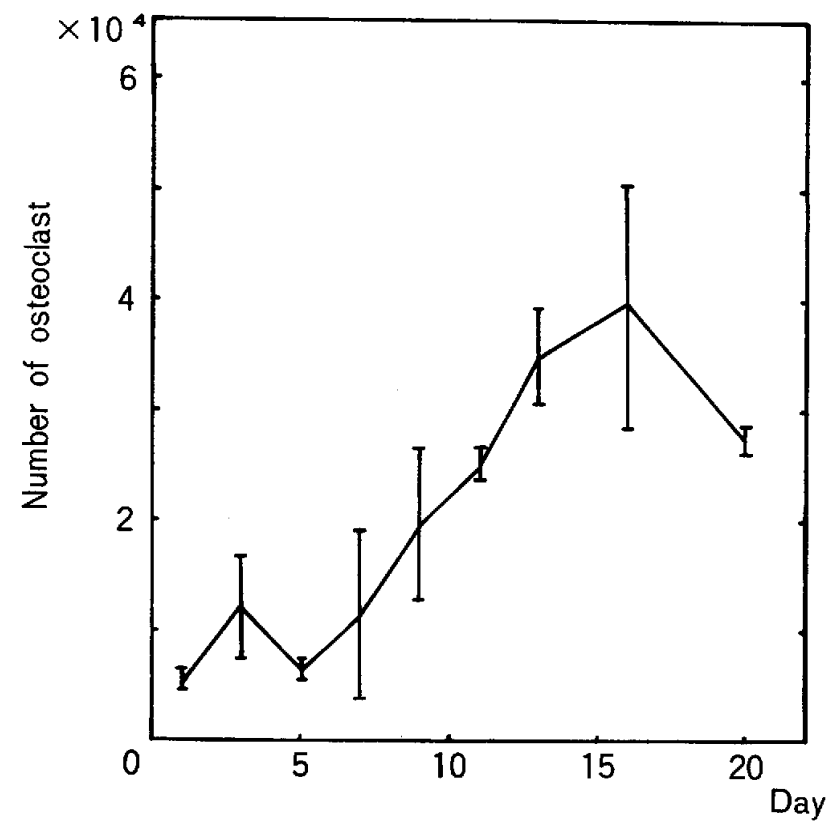

Fig. 1 Number of osteoclast in whole medulla after birth. The femora were taken at appropriate days and the cell suspension was prepared from two femora. Small parts of the suspension were smeared on the slide glass in order to count osteoclast number. The numbers shown are the averages of recovered osteoclast number per two femora in three separate experiments. The bars in Fig. 1 to 3 show standard deviations.

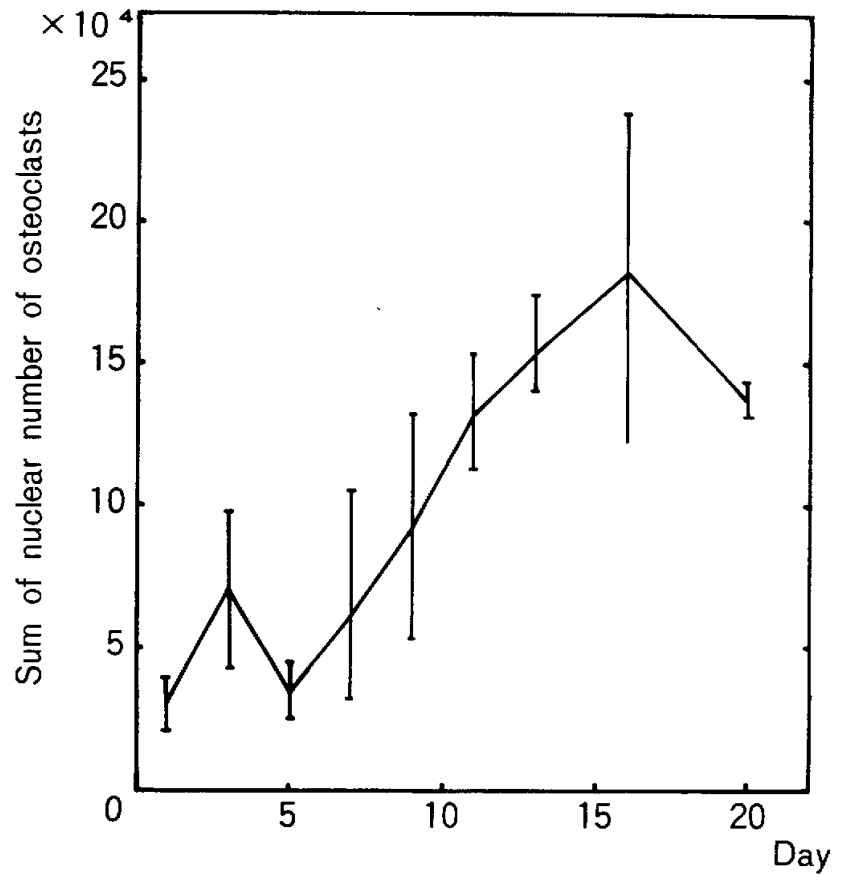

Fig. 2 The sum of nuclear number of osteoclasts in whole medulla after birth. The sum of the nuclear number of osteoclasts was calculated from the amplication of osteoclast number by the average nuclear number of about 40 cells at shown time. Refer to the caption for Fig. 1. 


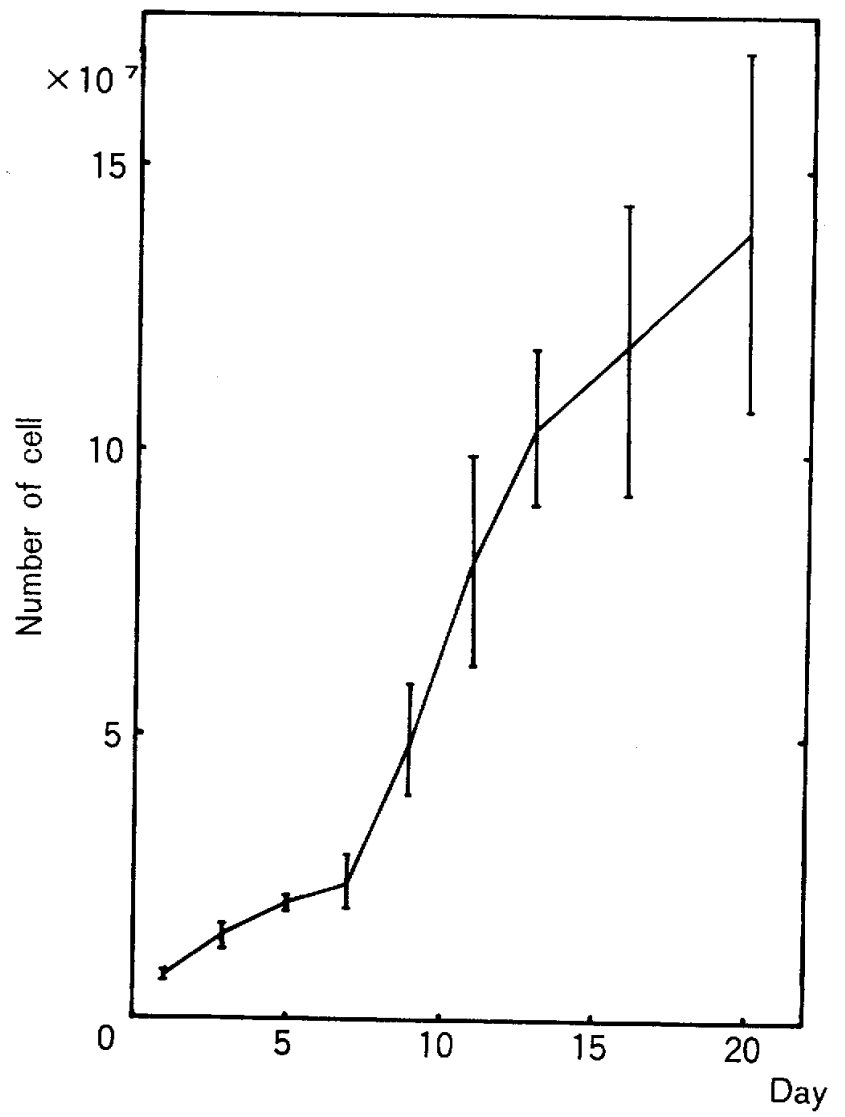

Fig. 3 Number of cell in whole medulla after birth. Refer to the caption for Fig. 1 .

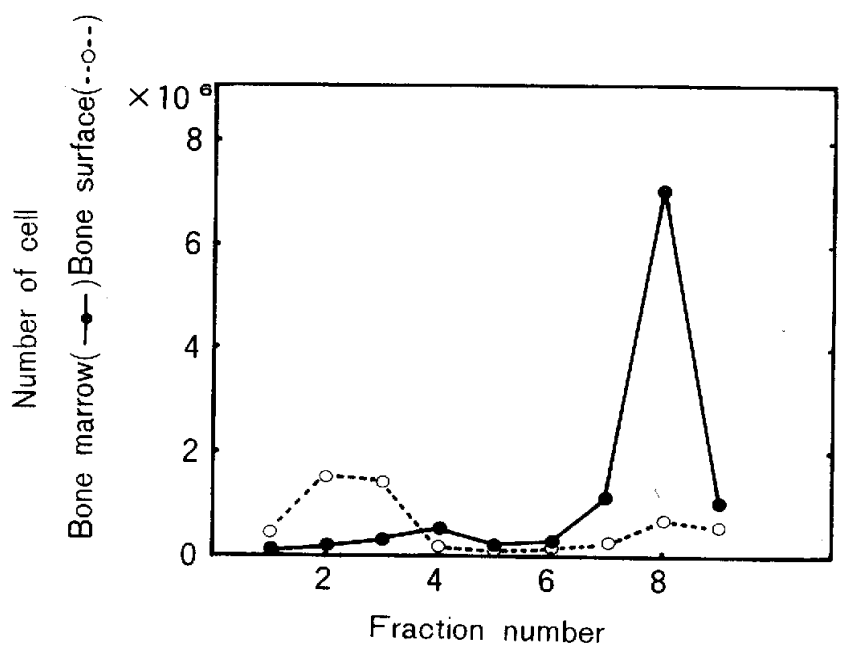

Fig. 4 Percoll gradient centrifugation of whole medullary cells of 11-day-old rat. Two maxima were observed and no other ones appeared from birth to 20th day. The first was recognized at Fra. 2 and Fra. 3 , called Fra. $2+3$. The second was done at Fra. 7 and Fra. 8 , called Fra. $7+8$. 20th day. The isolation of osteoclasts will be advantage our to prepare on $3 \mathrm{rd}$ day, although the maximum number of osteoclast was observed on 16 th day.

The Percoll gradient centrifugation was one of the useful method for enriching osteoclast from medullary cell suspension. Whole medullary cells were divided into two major groups, Fra. 2 and Fra. 3 (Fra. 2+3) and Fra. 7 and Fra. 8(Fra. $7+8)$, after Percoll centrifugation (Fig. 4). Most of osteoclasts were recovered constantly in Fra. $2+3$. The cells in Fra. $2+3$ were dominant in number in whole medullary cells upto 7 th day, and the number was comparatively constant thereafter (Fig. 5). On the other hand

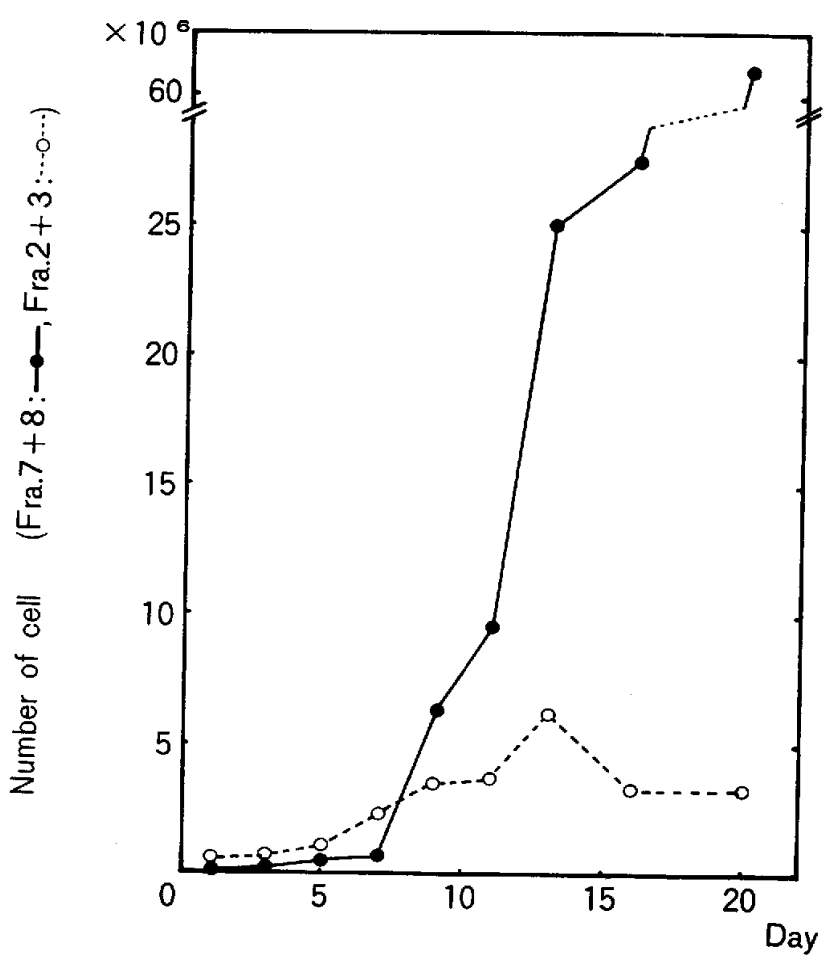

Fig. 5 Number of cell of Fra.2+3 and Fra. $7+8$ after birth. Whole medullary cells were divided into two major groups as Fig. 4 and the cell number in each group was counted at shown time. The similar result was obtained in a separate experiment. 
the cells in Fra. $7+8$ increased in number suddenly on 9 th day, and occupied the major part of medullary cells thereafter. Osteoclast number recovered and its recoveries after Percoll method changed from birth to 20th day (Fig. 6). They had two maxima observed on $3 \mathrm{rd}$ and 9 th day. In either case the earlier one appeared in the same time. But the later one of recovered osteoclast number was done several days earlier than the later one of that recovery.

Using the flashing of bone marrow cells, whole medullary cells could be divided into two cell populations; bone marrow cells and remaining bone surface cells. Osteoclast recovered preferentially in bone surface cell fraction rather than in bone marrow cell fraction ( 9 versus 1). On the Percoll gradient centrifugation the bone surface cells were recovered mainly in Fra. $2+3$ (Fig. 7). On the other hand bone marrow cells were recovered mainly in Fra. $7+8$. These results showed that the flashing could exclude the most of Fra. 7+8-cells with little loss of osteoclasts, although this method could little contribute to eliminate the contaminating cells in Fra. $2+3$.

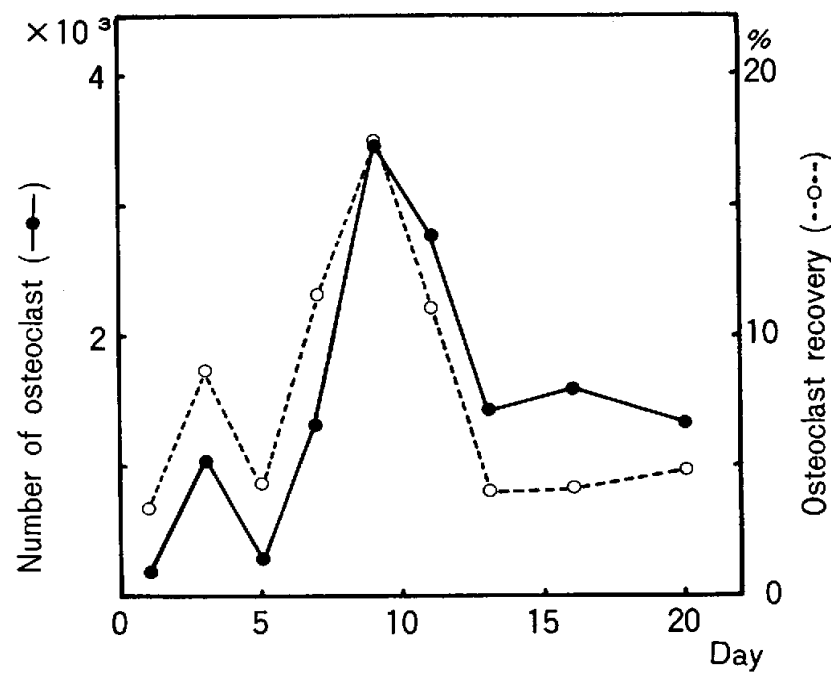

Fig. 6 Enrichment of osteoclasts by Percoll gradient centrifugation from whole medullary cells. Whole medullary cell suspension, prepared from appropriate-day-old rat, was applied on Percoll gradient centrifugation. A part of cells of each fraction was smeared on glass and stained by acid phosphatase activity to distinguish an osteoclast. Osteoclasts recovered in Fra. 1 to 3 were counted and their recoveries after Percoll fraction were calculated. The similar result was obtained in a separate experiment.

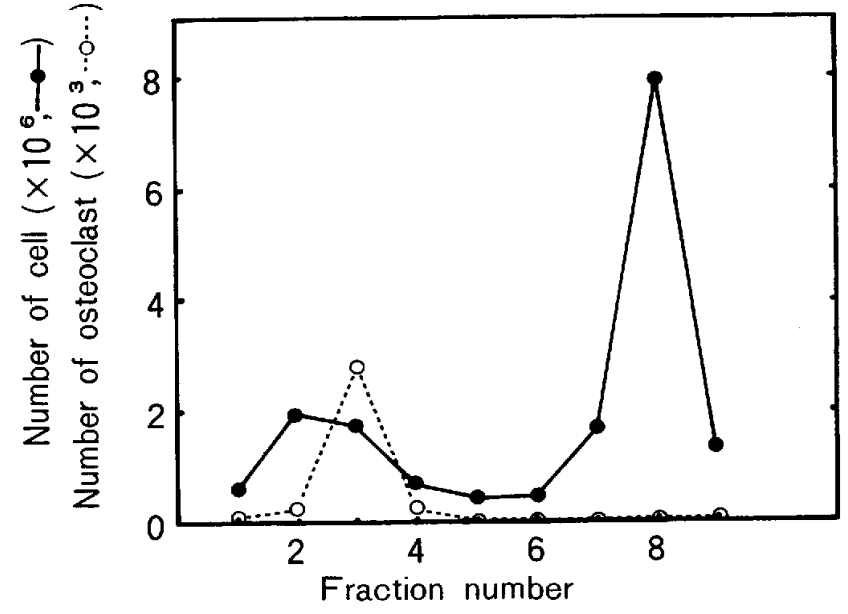

Fig. 7 Percoll gradient centrifugation of bone marrow cells and bone surface cells of 11-day-old rat. Two cell populations were prepared from two femora and applied on Percoll gradient centrifugation as described in the text. 


\section{Discussion}

The recovered osteoclasts changed in number having two maxima in a course of days after birth. The cells of whole medulla also rose in increasing rate. These profiles of changes have not been brought artificially by unsettleness of cell preparation, because the apparent recoveries of these cells were steady in practice during the expeimental period. Thus the phasic changes in the number of both osteoclasts and whole medullary cells will reflect the net changes of these cells. This is the first report of phasic changes in bone cells, although several authors have studied histologically the process of ossification in early growing bone ${ }^{7-9)}$.

The phasic change on 5 th day could be found also in bone weight, but not in bone length from our observation. The growth rate in length markedly slowed down since 12 th day after birth ${ }^{10}$. The profile of changes in bone weight was very similar to that in whole medullary cells occupied a large part in bone.

The cell suspension from 3rd day was the richest in proportion, though the number of osteoclasts in the suspension for each early day was considerably small. Several studies of isolated osteoclasts have been carried out only in this aged rat without any experimental causes ${ }^{3)}$. It was shown here, too, that the cell suspension from 16 th day included the largest number of osteoclasts of those from early days. The cell suspension from this day also included the other cells in a high degree, named here as Fra. $7+8$-cells. The cells of Fra. $7+8$ could be separated from osteoclasts by Percoll gradient centrifugation and also could be eliminated by the flashing of bone marrow cells. In the former procedure recovered osteoclast number on 16th day was not the greatest of those on any other days. The greatest number in recovered osteoclasts was achieved on 9th day. These were provided by the differences in osteoclast recovery. It is likely that a physiological state of the cell is reflected in the recovery, as the differences in recovery occurred through the same operation. The cell suspension from 9th day was one of the suitable sources of osteoclasts in a large scale of isolation.

The increase of osteoclast number means that osteoclasts are synthesized in de novo from precursor cells or activated from the resting cells. The decrease of osteoclast number means that osteoclasts are degradated into the cell fragments or inactivated to the resting cells. As discussed previously, the changes in osteoclast recovery possibly reflected the physiological state of osteoclasts. In fact ostoclasts occurred in two-day-culture from isolated whole medullary cells prepared on the day, when osteoclasts increased in number, but not the other days (manuscript in preparation). Thus early growing bone was also good material for studying the synthesis, activation, degradation or inactivation of osteoclasts.

It is also expected that the activity of osteoclasts will change in concert with the increase and the decrease in number. Certainly osteoclastic activities were observed only in cell suspension prepared during the increasing period in our preliminal study. 
Osteoclasts must be under the strong control of hormones or the other biologically active substances, because there are drastic changes of the cell both in the number and in the activity. In the same time the other bone cells, such as osteoblasts, may change in number and (or) in activity. Indeed majority of bone marrow cells, named Fra. $7+8$-cells, seemed to start synthesizing vigorously after 7 th day.

If one quantifies the same femora with succeeding sections, it needs long time to decalcify sample, the skill to cut a vast number of succeeding sections and the effort to count osteoclasts by microscope. These numbers of osteoclasts and whole medulla were still over $10^{5}$ and $10^{8}$, respectively. It seems to be impossible in practice to quantify these cell with succeeding sections of femora. The method for counting osteoclast number used here was rapid and specially useful in large materials. The authors also performed the quantification of osteoclasts by this method in alveolar bone of rat after tooth extraction ${ }^{11}$ ) and after lipopolysaccharide application to pulp (unpublished data). In these results recovered osteoclast number correlated highly with the observations of sections.

\section{Summary}

In order to raise the yield of osteoclasts, the numbers of osteoclasts were counted in the whole medulla of femora of rat from birth to 20th day. Most of osteoclasts were recovered from bone in a short term of curettage. The number of osteoclasts changes drastically in early growing bone. That had two maxima the earlier one on 3rd day was smaller than the later one on 16 th day. The whole medullary cell number increased day by day, and the rate of increase rose on 7 th day. Whole medullary cells were fractionated into 8 by Percoll gradient centrifugation from birth to 20th day. Osteoclasts were constantly recovered preferentially in Fra. 2 and Fra. 3. On Percoll centrifugation the first maximum appeared on 3rd day in the number of recovered osteoclasts. But the second one was done on 9th day. This was provided by the differences in cell recoveries, and the differences possibly reflected the physiological state of osteoclasts. Whole medullary cells could be devided by flashing into two cell populations; bone marrow cells and bone surface cells. As osteoclasts were preferentially recovered in bone surface cells, the exsistence of bone marrow cells was a disadvantage for osteoclast isolation. Bone marrow cells increased in number after 7 th day and flashing is useful after that to eliminate bone marrow cells. These results clarified the appropriate age for good yield of osteoclasts and showed the usuful method for eliminating the other cells. It was disucssed that these dramatic changes in osteoclasts reflected the synthesis and degradation, or the activation and inactivaton.

This work was supported in prat by a grant from the Ministry of Education, Science and Culture, Japan. 


\section{References}

1) Osdoby, P., Martini, M. and Caplan, A.I. : Isolated osteoclasts and their presumed progenitor cells, the monocyte in culture. J. Exp. Zool. $224: 331-344,1982$.

2 ) Zallone, A. Z., Teti, A. and Primavera, M.V. : Isolated osteoclasts in primary culture first observations on structure and survival in culture media. Anat. Embryol. $165: 405-413$, 1982 .

3 Chambers, T.J. : Phagocytosis and trypsin-resistant glass adhesion by osteoclasts in culture. J. Pathol. $127: 55-60,1979$.

4 Zallone, A.Z., Teti, A. and Primavera, H.V. : Resorption of vital or devitalized bone by isolated osteoclasts in vitro. The role of lining cells. Cell Tiss. Res. 235:561-564, 1984.

5 ) Boyde, A., Ali, N.N. and Jones, S.J. : Resorption of dentine by isolated osteoclast in vitro. Br. Dent. J. $156: 216-220,1984$.

6) Inoue, H., Iwanaga, S., Uchiyama, C. and Kawagishi, S. : Isolation of osteoclasts by Percoll gradient centrifugation from rat femora. Jpn. J. Oral Biol. $25: 1162-1163,1983$.

7) Bloom, W. and Bloom, M.A. : Calcification and ossification. Calcification of developing bones in embryonic and newborn rats. Anat. Rec. $78: 497-523,1940$.

8 ) Pratt, C.W.M. : Observations on osteogenesis in the femur of the foetal rat. J. Anat. 91 : 533-544, 1957.

9) Bhaskar, S.N., Einmann, J. P., Schour, I. and Greep, R.O. : The growth pattern of the tibia in normal and ia rats. Am. J. Anat. $86: 439-477,1950$.

10) Ho, D.-Z., Inoue, H., Iwanaga, S. and Uchiyama, C. : Quantitative studies of the macrophages and osteoclasts in extraction wound of rats. Jpn. J. Oral Biol. $26: 1444-1449$, 1984. 


\title{
ラット初期成長骨における破骨細胞と全骨髅 細胞数の日令依存変化
}

\author{
九州歯科大学口腔細菌学講座 (主任 : 内山長司教授) \\ 井上博 雅 - 何達人・内 山長司
}

ラット大腿骨より破骨細胞を多く分離するために, 生 後 20 日日まで大腿骨骨䯣内の破骨紐胞数を測定し, 多数 分離できる日令を調べた。全骨笾細胞懸濁液を塗抹し， 巨大で多核な酸性ホスファターゼ陽性細胞を破骨細胞と して計測した。本細胞数は生後 3 日目と16日目にピーク を示す大きな変動をし, 前のピークは小さく後のピーク は大きかった．本細胞の平均核数は4.6〜6.0の範囲で少 し変動した。全骨骵細胞数は日々增加し, 増加率は 7 日 目から13日目の間最も高かった。

全骨旤細胞をパーコール濃度勾配遠心をし，上層より 8 画分に分画した。破骨細胞は第 2,3 画分に常に分画 された. パーコール分画後・回収破骨細胞数は 3 日目に 最初のピークとなった。しかし第 2 のピークは 9 日目で
あった、パーコール前後で第 2 のピークがずれたとと は, 本細胞の回収率の違いに上り生じたもので, 本細胞 の生理状態の違いを反映したものと考えられた，全骨喵 紏胞は骨䯙洗浄により，骨鹃細胞と骨表面細胞の $2 \supset の$ 細胞集団に分けられた。破骨細胞は骨表面細胞中に常に 回収されるため, 骨髄細胞の存在は破骨細胞分離に不利 である，骨骨道細胞は 7 日目以後増加するため，てれ以後 骨髄細胞の洗浄はこの選択的除去法として有効である.

これらの結果は破骨細胞の回収率を高めるための適当 な日令と，他の胞胞を除く有効な方法を示している．ま た破骨細胞の劇的な変動は本細胞の新生, 分解または活 性化，不活性化を反映していることについて考察した。 